\title{
OBITUARIES
}

\section{Sir Ernest Barker, F.B.A.}

THE death on February 17 of Sir Ernest Barker, at the age of eighty-five, means not only the loss of a great scholar and teacher but also the loss of a symbol of what may well seem, in 1960 , to have been a happier and more confident world. Ernest Barker always denied being a 'scholar' in the old-fashioned Oxford and Cambridge classical sense. But all that that meant was that he was not one of the elaborately skilful composers in the ancient tongues whom Macaulay (who himself was a master of these dexterities) made fun of. Barker was a very distinguished product of the Oxford 'Greats' school. I suspect that he never lost his conviction, even after many happy years in Cambridge, that for the statesman and for the teacher of statesmen the school of Literae Humaniores was the ideal education.

It would be both absurd and unjust to suggest that Barker was an old-fashioned classic incapable of understanding or appreciating the contributions of more modern studies to the science (or as he would have preferred, I think, to put it) the art of politics. He preserved into his old age a great deal of curiosity about modern developments and modern contributions. But it would be also absurd to pretend that he was ever convinced that the modern American statistical analysts of political behaviour and, still more, the modern psychological explainers of political behaviour, have really improved on the study and explanation of the human situation provided by Plato, Aristotle, and St. Thomas Aquinas.

Barker wrote a great many books, all of them meritorious and some very remarkable. His essay on "The Crusades" for the "Encyclopædia Britannica", published as a little book, seems as remarkable to me now as it seemed when, as an undergraduate in Oxford, I had my attention directed to it by the late B. H. Sumner. In his old age he wrote what I am told was an extremely competent book on Byzantium. But I think that his greatest achievement was his "Political Thought of Plato and Aristotle"-a book full of learning and wisdom. I once reproached him for not producing a new edition and almost coaxed him into an admission that he had wasted a good deal of time on less-important things. $H_{\theta}$ did, in fact, produce a new volume on Plato, but never finished the complete revision of this masterpiece. He spent (or, as I think, wasted) an immense amount of learning on a translation of Gierke, which involved the resuscitation of a great many rightfully forgotten Germans. 'C'était magnifique', but it was not what we wanted from Ernest Barker. I think he came to feel this, for he does not cite this laborious and learned and in some ways useful work in "Who's Who".

Barker was a Liberal (both upper case and lower case letters), and that comes out in the admirable little volume he wrote in the Home University Library on English political thought "From Herbert Spencer to To-day" and in his "Principles of Social and Political Theory". He would never have understood that it was possible to separate politics from morals, to reduce politics to statistical description. As much as Dr. Gunnar Myrdal, he would have held that the idea of ethically neutral means was nonsense. Politics was about ethics. If this were not true, it was not worth serious study.

Barker was not only a man of prodigious learning, he was also a man of prodigious energy. At an age when most people think of retirement as a reality, nearly ten years after he had ceased to be professor of political science in Cambridge, he went to Germany, out of a strong sense of mission, to rehabilitate the lost German tradition of academic freedom. It was a task that might have daunted a younger man, and he suffered a very serious illness from which, some think, he never quite recovered, although he continued to work with an energy that would have shamed many men much younger than he was.

In addition to immense intellectual and physical energy, Barker was extremely handsome and had a most magnificent voice, which was made even more effective as it preserved its northern burr. There is a tradition in Peterhouse that he imagined he had lost this burr. Fortunately there was no basis for this illusion. He not only had an academic career of great distinction, but also one of great variety. From Manchester Grammar School he went to Balliol and was successively Fellow of Merton, St. John's, and New College, where he had a most admiring pupil in the late Harold Laski. He was, for a short and not very happy time, principal of King's College, London, and then he was, for a very long and happy time, the first professor of political seience in Cambridge and Fellow of Peterhouse. In contemplating Ernest Barker it was easy to think of him as a relic of a dead past. But it was much wiser to think of him as a representative of a great past, of the disciples of T. H. Green (and of Henry Sedgwick), of the moralistic and learned political philosophers of a great era of modern English history. He survived into what he must have thought--and did thinkwas an evil and distracted world. But he continued to be loyal to both his theory and practice. If sometimes he seemed unreceptive to new ideas, he was totally above the temptations of fashion or current academic prestige. "We shall not look upon his like again." "W. W. BroGAN

\section{Dr. Hsien Wu}

Dr. HsIEN WU, an authority on blood analysis, died on August 8, 1959. He was born in Foochow, China, on November 24, 1893. He attended a local high school in Foochow and then enrolled in the naval architecture course at the Massachusetts Institute of Technology. After two years, he changed his course to chemistry and was awarded the B.S. degree by the Institute in 1916. After remaining as an assistant in the Department of Chemistry for a year at the Institute, he entered Harvard Medical School in 1917 for graduate study with Dr. Otto Folin in the Department of Biological Chemistry, and received the Ph.D. degree in June, 1919. He continued his researches as a Fellow with Dr. Folin for a further year.

In 1920 , Dr. Wu returned to China as assistant in biochemistry at Peiping Union Medical College. After one year, he was raised to an associate and 
later placed in charge of the Department. In 1924, he was appointed an associate professor of biochemistry and in 1928 he was raised to professor and chairman of the Department of Biochemistry. He continued as chairman of the Department until January, 1942, when Japan took over the College. In March, 1944, he was called to Chungking to organize the Division of Nutrition and join the National Institute of Health. In July, 1944, the Chinese Government sent him to the United States as its nutrition expert on a special mission to study rehabilitation reconstruction programmes for post-war China. He served as director of the Nutrition Institute, Ministry of Health, until the end of 1947. He was also associated with the Institute as the director of its Peiping Branch during 1946-47.

In 1947 , Dr. Wu and five other Chinese scientists were invited by Unesco to attend the International Physiological Congress which was held at Oxford. On his return from the Congress, by way of the United States, in September, 1947, he was extended the privileges of a visiting scholar in the Department of Biochemistry, College of Physicians and Surgeons, Columbia University. In June, 1948, he was appointed a research associate at Columbia. Sensing the political situation in China, he finally made preparations to move his family to the United States.

Dr. Wu joined the Department of Biochemistry, Medical College of Alabama, Birmingham, on September 1, 1949, as visiting professor. Following a heart attack in October, 1952, he retired on September 30 and moved to Boston, Massachusetts, where he devoted his time to higher mathematies, Spanish and writing.

Dr. Wu was a member of an Administrative Committee of three functioning as director of Peking Union Medical College, 1935-37. He was a member of the Chemistry Division of the National Committee on the Standardization of Scientific Terminology during 1921-27; he served as editor of the Chinese Journal of Physiology, 1926, and continued on the editorial board until 1942; and was president of the Chinese Physiological Society, 1931--34.

Dr. Wu was a tireless investigator. His bibliography has 160 entries, which includes two books : "Principles of Nutrition" (1929) and "Principles of Physical Biochemistry" (1934). His fields of research included blood chemistry, gas and electrolyte equili. bria, nutrition, immunochemistry, proteins and the metabolism of amino-acids using amino-acids labelled with nitrogen-15 as tracer.

In addition to his contribution of the famous system of blood analysis he also was a pioneer in his researches and theory in other major areas. He made quantitative analyses of the precipitate from the antigen-antibody reaction following the use of labelled antigen. In 1928, he used hæmoglobin which was labelled with a coloured group. The next year, he reported the use of iodo-albumin as the antigen and he analysed the antigen precipitin precipitate for iodine and nitrogen content. These were the first analyses of this nature and antedated the use of isotopes for such analyses by several years. He also proposed the first reasonable theory of denaturation of proteins in 1931. Other valuable contributions to protein chemistry by Dr. Wu were his studies on the molecular weights and osmotic pressures of hæmoglobins of experimental animals in aqueous solution, 65 per cent glycerine solution and in concentrated urea. He noted that the molecular weights of oxy. hæmoglobins and hæmoglobins of dog and sheep are not changed in urea solution whereas those of ox and horse are reduced to one-half.

Emmett B. Carmichaed.

\section{NEWS and VIEWS}

\section{Pioneer 5}

The United States space probe Pioneer 5 was launched from Cape Canaveral in Florida at 13.00 U.T. on March 11, to become the third artificial planet of the Sun. The launching missile was a three-stage Thor-Able rocket, and the final-stage vehicle attained a velocity of about 6.9 miles per sec. relative to the Earth, in a direction nearly opposite to that of the Earth's motion around the Sun. Its residual velocity relative to the Sun, after escaping from the Earth's sphere of influence, was therefore less than the Earth's orbital speed, and its orbit is consequently smaller than that of the Earth : it is expected to be about 75 million miles from the Sun at perihelion, and about 92 million miles at aphelion, with a period of 311 days. At perihelion it will be near the orbit of Venus, which moves in a nearly circular path at a distance of 67 million miles from the Sun.

Pioneer 5, which weighs $90 \mathrm{lb}$, has a 5-watt radio transmitter for use near the Earth and a 150-watt transmitter for use at greater distances. The power is provided by solar batteries arranged in four 'paddlewheel' vanes. To conserve energy, the transmitter is to be switched on for only a few minutes each day, in response to commands from Earth. The radiotelescope at Jodrell Bank is the main tracking station, and the 150-watt signals should be received at distances out to about 50 million miles. If so, Pioneer 5 will be

within communication distance for about the next five months. Pioneer 5 carries various scientific instruments, including a high-energy radiation counter, an ionization chamber and Geiger counters to measure medium-energy radiation, a magnetometer to determine both the strength and direction of the magnetic field in space, and equipment for detecting micro-meteorites.

\section{Pharmacology at University College, London :}

Prof. F. R. Winton

Prof. F. R. Winton, who is retiring from the University of London chair of pharmacology at University College, was trained originally in chemistry and had been working for some time as an industrial chemist with the Mond Nickel Co. when he decided to take up medicine. He graduated M.D. (Cambridge) in 1926, and he obtained the D.Sc. (London) in 1942. After graduation, he worked with A. J. Clark in the Pharmacology Department of University College, London, and in 1931 returned to the Department of Physiology, Cambridge, first as lecturer and then as reader. In 1939 he was appointed to the London chair of pharmacology at University College, in succession to Prof. J. H. Gaddum. His earliest scientific work, carried out in conjunction with L. T. Hogben, dealt with the identification of a frog melanophoreexpanding hormone in the pituitary gland. His sub- 